\title{
E-Government Implementation: A Reflection on South African Municipalities
}

\author{
Tendani Mawela ${ }^{a}$, Nixon Muganda Ochara ${ }^{b, c}$, Hossana Twinomurinzi ${ }^{c}$ \\ a Department of Informatics, University of Pretoria, South Africa \\ ${ }^{b}$ Department of Informatics, Namibia University of Science and Technology, Namibia \\ ${ }^{c}$ School of Computing, University of South Africa
}

\begin{abstract}
The objective of the paper was to understand the challenges towards e-Government implementation in South Africa. The paper contributes to the ongoing discussion regarding the challenges facing e-government implementations in developing nations. It presents the outcomes of several discussions conducted with representatives from the municipal sector. These included semi structured interviews and a workshop with 40 attendees resulting in qualitative primary data. Through the application of an inductive thematic data analysis, the paper reflects on the critical role that municipalities hold in pursuing e-Government. It further discusses the different stakeholders that may influence the manifestation of e-Government for municipalities. It also highlights the barriers identified by respondents that require consideration from local government. The barriers include governance related issues, access to resources, leadership, ICT skills and funding.
\end{abstract}

Keywords: e-Government, ICT for development, municipalities

Categories: • Applied computing $\sim$ Computing in Government • Applied computing $\sim$ E-Government

\section{Email:}

Tendani Mawela tendani.mawela@up.ac.za (CORRESPONDING),

Nixon Muganda Ochara nixon.muganda@gmail.com,

Hossana Twinomurinzi twinoh@unisa.ac.za
Article history:

Received: 6 December 2016

Accepted: 12 June 2017

Available online: 9 July 2017

\section{INTRODUCTION}

We live in a world that has seen a multitude of scientific and technological innovations and advances. One arguably revolutionary innovation has been the advent of the Internet. The Internet along with various other Information and Communication Technologies (ICTs) has drastically changed the operations of private business, government and the non-profit sector. These organisations have chosen to utilise ICTs to survive in an increasingly dynamic, demanding and complex world. Furthermore, organisations have seen expectations for value and quality of services rise from their various stakeholders (Devadoss, Pan, \& Huang, 2003). In response, governments, businesses and charities alike have invested in ICT solutions with the hope of fulfilling some of the expectations of their stakeholders.

Mawela, T., Ochara, N.M., and Twinomurinzi, H. (2017). E-Government Implementation: A Reflection on South African

Municipalities. South African Computer Journal 29(1), 147-171. https://doi.org/10.18489/sacj.v29i1.444

Copyright (C) the author(s); published under a Creative Commons NonCommercial 4.0 License (CC BY-NC 4.0).

$S A C J$ is a publication of the South African Institute of Computer Scientists and Information Technologists. ISSN 1015-7999 (print) ISSN 2313-7835 (online). 
In the public sector, ICT investment primarily manifests itself as Electronic Government (eGovernment) programmes. The world has witnessed numerous e-Government projects (Irani, Love, \& Jones, 2008) and sub-Saharan Africa is no exception. E-Government projects are a reality for the African continent as seen with the numerous governments that have expressed strategies outlining plans for the implementation of a variety of e-government initiatives. However, even with various strategic plans and policies, the core challenge remains with the minimal successful implementations of e-government projects (Heeks, 2010; Irani, Elliman, \& Jackson, 2007; Irani et al., 2008).

Various researchers have raised concerns at the success rate of e-Government initiatives, which the majority have been cited as not delivering on the expectations of stakeholders. Researchers have studied the failure rates of various ICT led projects in the public sector (Heeks et al., 2003; Gauld, 2007; Heeks, 2010; Irani et al., 2008) and several have questioned the actual impacts of ICT on the development of countries (Harindranath \& Sein, 2007; Oghogho, 2013; Sein \& Harindranath, 2004).

This paper seeks to understand the challenges faced by South African Municipalities in their endeavours to implement e-Government and use ICTs towards the development of their communities.

This paper is an extension of a conference paper (Mawela, Ochara, \& Twinomurinzi, 2016) submitted to the SAICSIT 2016 conference.

\section{LITERATURE REVIEW}

\subsection{E-Government in sub-Saharan Africa}

A popular model for comparing various nations' e-Government programmes is found in the United Nation's e-Government Survey. The survey seeks to assess and compare countries according to their level of e-Government preparedness and also reviews the extent to which citizens participate and interact with e-Government programmes (United Nations Secretariat Department of Economic and Social Affairs, 2014).

The comparison of regions within the United Nations report indicates that Africa although steadily improving is lagging behind other regions with regards to e-Government development. The concern about African countries lagging behind has even seen the formation of an organisation with the objective of improving ICT development in Africa (Evans \& Yen, 2006) namely the African Information Society Initiative.

Another comparative study is the EIU's Digital readiness report that reviews the use and development of ICT in various countries in the world. The study assesses a country's availability and acceptance of ICT, as well as the "social, cultural and economic building blocks necessary" for the effective use of ICT (Economist Intelligence Unit, 2010, p. 7).

It is reported that in the African context the roll out of e-Government is often slow and centred around urban metropolitan cities and thus isolating those in the rural areas (Evans \& Yen, 2006). The United Nations highlights that

the key challenge for the e-Government development of Africa remains the widespread lack of infrastructure and functional literacy. Despite recent expansion in mobile telephony, most countries in Africa remain at the tail end of the digital divide. These 
challenges have translated into a lower than world average e-government development for all sub-regions. (United Nations Secretariat Department of Economic and Social Affairs, 2008b)

Therefore, as Schuppan (2009) explains, e-Government strategies and projects for Africa need to be adapted to account for factors such as illiteracy, rural area problems, and weak infrastructure, through the development of adequate access methods. Furthermore, Schuppan (2009) also warns that although the e-Government rhetoric from developing countries is often quite similar to that originating from industrialized countries, the problems that need to be addressed by e-Government are not automatically the same thus the exporting of e-Government models from developed countries to developing countries is not favourable. However, Bwalya (2009) argues that the African continent cannot be excluded from the paradigm shift of e-Government and many African leaders have accepted the concept of e-Government.

\subsection{The significance of the local government sector for e-Government}

Government in South Africa, undoubtedly faces various challenges in delivering services including: slow response rates to citizens requests, lack of customer service orientation from public sector staff, limited and inconvenient hours offered by government institutions and long distances to reach government offices (particularly in rural areas) (Nkosi \& Mekuria, 2010). It is argued that local government is at the forefront of understanding citizen's needs and is the 'delivery arm' of government. It is the obligation of municipalities to ensure that there is an improvement in services for underdeveloped communities. This will ensure that there is an equitable provision of services to all citizens (South African Local Government Association, 2014).

The importance of this level of government can be seen in the spate of so called 'Service Delivery Protests' that are primarily against poor service delivery and the absence of accountability by local councilors (Alexander, 2010). Groups of citizens across South Africa have undertaken these protests to ensure that government listens to them and in the hope that they will implement changes for the benefit of citizens. It is at local government that significant changes that impact the lives of the community can be initiated. Hence, this study focused on understanding the implementation of ICTs at this 'tactical' level of government within municipalities.

Researchers believe South African municipalities can trigger e-government programmes that allow citizens as well as business to interact with government using the full range of electronic media, through incorporating relevant measures in growth and development strategies (GDS) and integrated development plans (IDP) (Abrahams \& Newton-Reid, 2007). Therefore, it can be argued that the local governments which are closer to the communities are best poised to deliver on a vision of e-government. The interest of the study was not merely on the technology, but on the tangible improvements it can bring to constituents:

The real benefit of e-Government lies not in the use of technology per se, but in its application to processes of transformation. (United Nations Secretariat Department of Economic and Social Affairs, 2008a) 


\subsection{E-Government implementation benefits and challenges}

E-Government is an area that is growing within the information systems research domain (Dwivedi, Williams, Rana, \& Williams, 2011; Irani, Sahraoui, Ozkan, Ghoneim, \& Elliman, 2007). E-Government is an evolving discipline and broadly encapsulates the governmental activities that are influenced by and make use of ICTs (Brown, 2005). The oft cited driver behind e-Government is the increasing expectations of citizens stemming from their e-commerce experiences (Edmiston, 2003) thus pushing the public sector to offer electronic services, enhance democratic processes and improve efficiency. The benefits expected from e-Government include innovations that can facilitate the efficient delivery of government services which creates public value (Karunasena, Deng, \& Singh, 2011; Weerakkody, Irani, Lee, Osman, \& Hindi, 2015). E-Government may empower public sector organisations to operate better and achieve desired goals. Also, e-Government can enable the building of trust between a government and citizens (Karunasena et al., 2011).

Various reasons are highlighted for the failure of e-Government interventions. These include: e-Government projects are inherently risky, complex, non-linear and very technical in nature (Brown, 2005; Ebbers \& Van Dijk, 2007). The on-going threat of the digital divide has also been cited where certain groups in society lack access to ICTs (Cloete, 2012; Davison, Wagner, \& Ma, 2005; Mutula, 2005; Anthopoulos, Reddick, Giannakidou, \& Mavridis, 2016). Also, there is insufficient funding to spend on ICT and high operational costs (Ebrahim \& Irani, 2005; Heeks, 2002; Tat-Kei Ho, 2002); partnership and collaboration across public, private and non-profit sectors is lacking (Ndou, 2004); a lack of e-readiness necessary for implementing e-Government initiatives. E-Readiness incorporates the necessary technical infrastructure, data systems, policy issues and legal environment, human capital and skills, as well as a supporting strategy and leadership commitment (Heeks, 2002; Ndou, 2004; Mutula \& Mostert, 2010; United Nations Secretariat Department of Economic and Social Affairs, 2008b).

Other reasons for failure are that often e-Government initiatives are driven by external and mostly western agendas (Heeks, 2002); there is a complex and turbulent global political environment coupled with change management issues (Ndou, 2004; Chou, Chen, \& Pu, 2008). Additionally citizen trust is cited (Alsaghier, Ford, Nguyen, \& Hexel, 2011; Warkentin, Gefen, Pavlou, \& Rose, 2002). Lastly, the resistance from public sector employees (Chou et al., 2008) and a lack of integrated project planning and effective management along with relevantly skilled IT staff and project managers are also cited (Reffat, 2003; Ebrahim \& Irani, 2005; Thomas, 2009; Andrade \& Joia, 2012; Y.-C. Chen \& Gant, 2002; Cloete, 2012; Weerakkody et al., 2015).

\subsection{E-Government outcomes}

Scholars have purported that e-Government projects have seen more failures than successes (Anthopoulos et al., 2016; Guha \& Chakrabarti, 2014; Heeks \& Molla, 2009; Nurdin, Stockdale, \& Scheepers, 2012). For example the, World Bank has acknowledged that a significant portion of their ICT related investments have been largely unsuccessful (Independent Evaluation Group, The World Bank, 2011). The organisation indicates that

with respect to ICT applications, 74 percent of World Bank projects had ICT components, 
but the Bank Group's record has been modest, reflecting the intrinsic high risks in the implementation of information technology (IT) projects. (Independent Evaluation Group, The World Bank, 2011, p. vii)

In their paper, Mutula and Mostert (2010) cite some South African examples of e-Government projects that did not meet stakeholder expectations. These include the Golaganang project that was to provide government employees with cost effective ICT resources and address their digital literacy needs however it failed to launch. Alternatively a project for the National Welfare Agency which did start with an intention to rollout over three years was found to have only reached $40 \%$ of their goals in the sixth year of the project with higher than anticipated costs (Mutula \& Mostert, 2010).

Heeks (2005) highlights that there are three main types of outcomes for e-Government projects namely: Firstly, a total failure: the initiative was never implemented or was implemented but immediately abandoned. Secondly, a partial failure: major goals for the initiative were not attained and/or there were significant undesirable outcomes. Finally, a successful project: where most stakeholder groups attained their major goals and did not experience significant undesirable outcomes. Further to this although there is limited data; it is estimated that approximately 35 per cent of e-Government projects are total failures, 50 per cent are partial failures, and 15 per cent are successes. This high failure rate is disappointing particularly from the perspective of the poor that rely on their governments to utilise resources in the most efficient manner to benefit society.

This research paper endeavoured to address the question: What are the barriers towards eGovernment implementation in South African Municipalities?

\section{RESEARCH METHOD}

The study was exploratory and qualitative in nature. The research reviewed raw data from interviews and a workshop with representatives from local government. The population that was relevant to this study of local government were the 278 different municipalities of South Africa. This comprises of eight metropolitan municipalities (referred to as Category A municipalities), 226 local municipalities (referred to as Category B municipalities) and 44 district municipalities (referred to as Category C municipalities). The sampling technique selected for this study was judgement (purposeful) sampling. We actively searched for the most productive sample to answer the research questions. Candidates that were targeted for participation in this research were initially highlighted as the following: Municipal Managers or Project Sponsors or the equivalent including the Office of the Mayor where applicable; The Information Technology Manager or Chief Technology Officer or Chief Information Officer of a Municipality or the equivalent; and Project Manager/Consultant or equivalent for a Municipality Technology Project.

The data was collected from a workshop with 40 attendees from various municipalities and an additional five semi-structured interviews were conducted (Table 1).

The interviews and workshop were recorded and were transcribed. This resulted in qualitative primary data encapsulated in the transcripts. The transcripts were uploaded into Atlas.ti 7 (version 
Table 1: Sample profile

\begin{tabular}{|c|c|c|}
\hline Role & No. of interviews & Location \\
\hline Municipal ICT manager & 1 & $\begin{array}{l}\text { Mpumalanga province, South Africa } \\
\text { (based in a Category B municipality) }\end{array}$ \\
\hline Municipal ICT manager & 1 & $\begin{array}{l}\text { Mpumalanga province, South Africa } \\
\text { (based in a Category C municipality) }\end{array}$ \\
\hline $\begin{array}{l}\text { ICT consultant on local } \\
\text { government projects }\end{array}$ & 1 & $\begin{array}{l}\text { Sub-Saharan Africa (consulting on pro- } \\
\text { jects based in central Africa) }\end{array}$ \\
\hline $\begin{array}{l}\text { ICT consultant on local } \\
\text { government projects }\end{array}$ & 1 & $\begin{array}{l}\text { Sub-Saharan Africa (projects based in } \\
\text { the western region of southern Africa) }\end{array}$ \\
\hline $\begin{array}{l}\text { Manager of local government } \\
\text { organisation }\end{array}$ & 1 & Gauteng province, South Africa \\
\hline Municipal ICT managers & Workshop of 40 attendees & $\begin{array}{l}\text { Representatives from } 9 \text { provinces in } \\
\text { South Africa (from all municipal categor- } \\
\text { ies) }\end{array}$ \\
\hline
\end{tabular}

7.0.81). The computer-aided techniques within the software were used to help categorise the text and identify pertinent concepts and themes.

The overarching approach for analysing the data for this study was the Inductive Thematic Analysis method. The thematic approach to qualitative data analysis, applied in this study, was as described by Braun and Clarke (2006).

One study reflected on the existing e-Government literature to elevate obstacles faced in these complex projects (Van Veenstra, Klievink, \& Janssen, 2011). The obstacles included governance related barriers, organisational and managerial barriers and also technological and other resource barriers (Van Veenstra et al., 2011). These were utilised as main organising themes coupled with citizen factors for discussing the research results as outlined in Table 2.

The following section discusses the findings based on the thematic areas outlined above. The discussion focuses on some of the pertinent issues raised by municipal representatives on the application of ICT for development and service delivery. It came through quite distinctly from several respondents that municipalities understood how important the role of local government is. Some respondents expressed that they do believe that they are uniquely poised to deliver on the transformation that citizens are expecting from government. As two managers highlighted:

Local municipalities are the base of the pyramid and without it none of the other tiers can exist. (ICT Manager, Interview 1)

Municipalities are close to the ground so they can have huge impacts in terms of job creation and all those things. (ICT Manager, Interview 5)

However, service delivery has 'fallen short of citizen aspirations and the government's goals' (The World Bank, 2011, p. 1) and some municipalities acknowledged this. 
Table 2: Municipal e-Government Discussion Themes

\begin{tabular}{|c|c|}
\hline Thematic area & Key sub-themes \\
\hline Governance & $\begin{array}{l}\text { - Profile of ICT Function } \\
\text { - Sustainability of ICT Projects } \\
\text { - Monitoring \& Evaluation of ICT Projects }\end{array}$ \\
\hline Organisational \& Managerial & $\begin{array}{l}\text { - Silo Operations in Government } \\
\text { - Municipal Leadership } \\
\text { - Stakeholder Management } \\
\text { - ICT Project Champion }\end{array}$ \\
\hline Access to Resources \& Technology & $\begin{array}{l}\text { - Local Government Context } \\
\text { - Funding } \\
\text { - ICT Skills }\end{array}$ \\
\hline Citizen Factors & $\begin{array}{l}\text { - Trust } \\
\text { - Language } \\
\text { - Electronic Participation }\end{array}$ \\
\hline
\end{tabular}

\section{FINDINGS AND DISCUSSIONS}

\subsection{Governance}

\subsubsection{The profile of the ICT function}

It became evident in the discussions with municipal ICT managers, that the ICT department within municipalities was not receiving the necessary attention due to the low profile that it held. ICT was not seen as an important department like the service departments (e.g. Electricity, Water and Sanitation departments). However, within the support departments it also didn't have much clout as compared to more established support functions (e.g. Finance or Audit).

The ICT person has to change the perception of ICT and the role of ICT. If they don't then ICT will have little or no impact. (Local Government Authority, Interview 2)

IT is not a backroom function but is part and parcel of trying to achieve this responsive and accountable local government. (ICT Manager, Workshop Transcripts)

Has ICT achieved visibility like for e.g. Finance which is seriously embedded in municipal systems? (ICT Consultant, Workshop Transcripts)

The raising of the profile of ICT may also be dependent on how it is placed in the organisational structure. As one ICT manager explains, this has helped them immensely:

Leadership is very important and he has taken Information and communications technology (ICT) upward and situated it in his department. We are opposite the municipal 
manager and that is where it should be strategically placed. Because one, we have direct communication with the municipal manager, he has hands on access as to what is happening within the municipality where ICT is concerned plus we have direct access to all the other offices. If we were in finance we would have to go through the CFO, then up to the municipal manager, now we have direct contact with all of the managers and all the deputy managers down to the clerks and as you have seen in the short time you have been here the interaction works. (ICT Manager, Interview 1)

Thus a considerable enabler for the ICT department to achieve their goals of supporting transformation is that of its positioning within the municipality. This is coupled with the power and voice it has in influencing strategic decisions. It is interesting to note that the South African Local Government Association (SALGA) has recommended that municipalities place ICT directly reporting to the municipal manager (Smith \& Cohen, 2012).

It has been lamented that often organisations fail to take advantage of technologies to drive organisational strategy (Damianides, 2005). The control and governance of ICTs may be enhanced to support the performance and sustainability of government's goals (De Haes \& Van Grembergen, 2009). This control and governance largely depends on ICTs positioning within the government organisation. Thus municipalities are encouraged to consider the structure of their ICT departments for the purposes of service delivery and development. This is due to the critical role of ICTs in creating an enabling environment for the delivery of organisational objectives (De Haes \& Van Grembergen, 2009).

\subsubsection{Cyclical nature of government}

Social sustainability of ICT programmes is important for the longevity of the impacts that are often called for. The sustainability of e-Government projects also came under the spotlight. It remains a vexing issue and one of the reasons provided is due to the cyclical nature of how governments operate. Thus the political and executive management has a short term view since they are not guaranteed to be in their positions after a period of 5 years.

I worry as with all government projects, that there's never a plan for how to maintain sustainability, never, and it's the nature of government. Governments have the lifespan of five years, and they do things for the election and then the elections come and then there's a slowdown and priorities change. (Local Government Consultant, Interview 3)

So, if there is a way, ICT can be linked to those priorities, maybe then ICT can find a place in development. (Local Government Consultant, Interview 4)

In essence the sustainability of e-government requires an assessment of alternatives that can help redress unintended consequences related to e-government and its longevity in the long run (Ali \& Bailur, 2007). 


\subsubsection{Evaluation of e-Government projects}

Respondents also deliberated on how the success of projects is defined in municipalities. Some municipalities believed that government ICT projects are experiencing high failure rates. While others thought that perhaps our notion of failure and success needs to be adjusted.

I think we're not doing well in the African context itself. That is what has been the challenge; we have a lot more failed projects than successful projects which has serious implications. (ICT Manager, Interview 5)

Other people say all these projects are failures; I think that they are projects which have laid a basis on which you can build on to do other things. I think looking at those projects in isolation is wrong but if you consider them as building blocks to much broader objectives, then I would not rush to call them failures. (Local Government Consultant, Interview 3)

The challenges in understanding the failures or successes of the e-Government projects may be rooted in a lack of an appropriate measuring and evaluation framework that takes into account the municipal context:

Currently the measures are not clear I think that is the problem. How do you monitor, assess the impacts or the benefits of ICT... We currently use the SDBIP ${ }^{1}$ and then we also look at the budget those are not ideal ways of measuring the impact. (ICT Manager, Interview 5)

I think the monitoring and evaluation is a challenge in municipalities. (ICT Manager, Interview 2)

The literature is also in disagreement since some scholars indicate that the majority of e-Government projects are failures however others indicate that there is an acute lack of empirical evidence particularly for the African context (Dada, 2006; Heeks, 2002; Ndou, 2004; Müller \& Skau, 2015).

\subsection{Organisational and managerial aspects}

\subsubsection{Silos in government}

It was noted in the discussions that a culture of operating in silos appears to be evident in some areas of government. This increased concerns from ICT managers that it may further delay service delivery.

\footnotetext{
${ }^{1}$ The Service Delivery and Budget Implementation Plan (SDBIP) details the implementation of service delivery and the budget for the financial year in compliance with the Municipal Finance Management Act(MFMA), 2003 (Act 56 of 2003). The SDBIP serves as a contract between the administration, the Council and the community, expressing the objectives set by the Council as quantifiable outcomes that can be implemented by the administration over the next twelve months.
} 
That is something that we are talking to them about now, but that is a resource that has to be shared across different ministries but you find that the survey general wants to set up his database, the Ministry of Mines wants to set up their own, the Ministry of Lands wants to set up their own. So, it's a very difficult one. So, it defies the whole idea of doing a totally connected solution. (Local Government Consultant, Interview 3)

The larger municipalities tend to want to do their own thing. We haven't been able to get much joy from them. (Local Government Consultant, Interview 3)

The municipalities indicated that although they appreciate support they would want to maintain some autonomy in terms of how they run their ICT programmes. This may indicate a strain in the relationship with national and provincial government but also entrenched the notion of silo operations.

So it is evolving, but it needs to evolve naturally and not be forced. If a decree comes down from government, national government that everybody has to have open source software regardless can you imagine the chaos... They are trying to have one financial system for the whole country, it is not feasible. (ICT Manager, Interview 1)

The culture of silos may find its roots in the pressurised environment that government departments find themselves to deliver on services and address the backlog that is currently plaguing the system. The World Bank reports that Government programs have become silos that are supply driven, focused only on the outputs and not on the citizen's needs (The World Bank, 2011). This emanates from how governments have historically organised themselves for managerial efficiency and service specialisation resulting in silos. E-Government was anticipated to demolish the silos and assist governments in becoming more integrated and citizen centric (Krishnaswamy, 2006). The municipalities included in this study have not yet fully experienced this.

\subsubsection{Municipal leadership}

The respondents felt very strongly about the notion of leadership within the municipalities. In the workshop this issue was reiterated by representatives from several different municipalities. They felt overwhelmingly that they do not have the necessary support of their political leadership or executive management with regards to using ICTs to support service delivery. As several managers complained:

Our biggest pain is getting politicians to talk to ICT issues. Also the second part is the challenge of getting the executive management to drive ICT governance and implementation. (ICT Manager, Workshop Transcripts)

We have been talking for the last 5 years. (ICT Manager, Workshop Transcripts)

There was a Communiqué sent from the minister. It came through the municipal manager's office and they took it straight to the IT office but with no directives given to IT (ICT Manager, Workshop Transcripts) 
It doesn't matter how good the plans that we come up with here are or how good the intentions at our level are. We will never get it through until the leaders at management and at political level are the ones driving the process. (ICT Manager, Workshop Transcripts)

The respondents indicated that although they did not have sufficient support from the leadership the requirement to deliver was not reduced.

You see at the level of the politicians they just want to see tangibles. They want to see assistance with delivering services that people can see (ICT Manager, Workshop Transcripts)

However, not all was lost with a few representatives highlighting that they at least have supportive leadership that embraces the role of ICTs in municipalities, indicating that having supportive political leadership is important.

We have a very forward thinking Municipal manager. (ICT Manager, Interview 1)

We have a very active GITOC ${ }^{2}$ and support from premier. The premier drives it and ICT governance is on the agenda. We are lucky in a sense, and it's much easier. (ICT Manager, Workshop Transcripts)

We are fortunate enough to have a progressive municipal manager but a lot of the municipalities don't see the relevance and it is very disheartening for a person like me if they are not going to get the support. (ICT Manager, Interview 1)

The extant literature argues that strong political leadership is a necessity for the success of eGovernment programmes (Furuholt \& Wahid, 2008). The data from this study indicates that some municipalities are in desperate need of political leadership with the foresight to put e-Government onto the "agenda and make it happen" (Furuholt \& Wahid, 2008, p. 4).

\subsubsection{Stakeholder management}

Municipalities have a range of stakeholders with which they must maintain relationships throughout the planning and delivery of services. These may include for example: businesses, non-profit organisations and citizens. As the City of Tshwane Municipality indicates it is essential that municipalities maintain communication with stakeholders. This is important for ensuring that community members are provided the opportunity to contribute to decisions affecting what happens in their communities (City of Tshwane Mayoral Committee, 2008). It is also accepted that municipal stakeholders have a significant role to play in the delivery and success of e-Government (Rowley, 2011). However, respondents acknowledged the inherent complexity in stakeholder management because of the sheer number of stakeholders that municipalities interface with.

\footnotetext{
${ }^{2}$ GITOC is the Government Information Technology Officers Council. It is the principal inter-departmental forum focusing on ICT and information management in the South African public service. Its two major roles are to advise government on ICT policies and strategies; and to bring CIOs together to collaborate on common solutions.
} 
Communications is very important both with the staff you have internally and then conveying that communications on a larger scale from the municipality to the stakeholders or citizens. (ICT Manager, Interview 1)

The problem is they don't understand it takes three to five years to understand the legislative processes which guide them. (ICT Manager, Interview 5)

The multitude of stakeholders that municipalities have further exposes them to external pressures to deliver and be more efficient (Moon, 2002). Therefore it is challenging and takes a large amount of time and other resources to maintain the various stakeholder relationships whilst remaining responsive to citizens' needs. Regardless of the complexity, municipalities need to "know more about who their stakeholders are, and what they want, to succeed in e-government service adoption" (Rowley, 2011, p. 54). This will assist in driving the developmental impacts of e-Government. How this may be achieved is through the careful identification of stakeholders; understanding of their varying interests and the drafting of relevant strategies that aim to support the participation of stakeholders in municipal projects such as e-Government (Rowley, 2011).

\subsubsection{ICT Project Champion}

When quizzed about what may improve their ICT operations and the role of ICT in local communities, one of the areas that municipalities indicated was around a champion being critical for change.

If you look at all successful projects there is always one person who stands out along the line, at each level and he is absolutely fabulous. He has got a team around him. (ICT Manager, Interview 1)

In my experience, the projects that have succeeded are because they've got this champion. This champion is someone that's fairly senior, it's someone that's respected up and down, he's respected by his bosses, and he is respected by his juniors. He has got enough influence to get things to happen. (Local Government Consultant, Interview 3)

The need for change agents and sponsors for e-Government projects has been cited by some scholars (see, for example, Almarabeh and AbuAli (2010); Chou et al. (2008); Ndou (2004)). It appears to be agreed upon that senior executive sponsorship is a critical success factor (A. J. Chen, Pan, Zhang, Huang, \& Zhu, 2009; Scholl, 2005) for e-Government success and this view was also held strongly by the respondents.

\subsection{Access to resources and technology}

\subsubsection{Municipal context}

The respondents expressed that local municipalities face a very different environment than their counterparts in provincial or national government. National and provincial governments define 
policies and often leave it to the local government to make sense of policies and drive implementation. Respondents outlined that they often believe that the other tiers of government are not aware of the realities within which they try to deliver services. South Africa is a country of contradictions, faced with poverty, unemployment and a high skills deficit (Statistics South Africa, 2011). These pressures are most evident in the local government context. This was especially pertinent in the context of rural municipalities. For example the ICT managers indicated that the rural areas require special attention to address the digital divide that still persists if ICTs are to be used to change citizens' lives. The constraints mentioned included the issue of distance, the lack of electricity and connectivity remains pertinent. As one respondent lamented:

Now, I think that place is 1000 kilometres or so. It is so far that we are being told that if somebody gets sick, they will just wait for that person to get well on his own or just to die. (Local Government Consultant, Interview 4)

There was no connecting; in all those places, that we went to there was no network. (Local Government Consultant, Interview 4)

The literature supports this finding since the digital divide has been consistently cited as a key problem for extending the reach of ICTs to citizens. The literature also indicates that those that do not have the necessary ICT skills, cannot access information for economic opportunities and thus fail to benefit from e-government (Almarabeh \& AbuAli, 2010).

\subsubsection{ICT skills}

Skills were considered quite high up in importance for attaining an ICT department that is able to support municipal objectives and drive developmental objectives. As one ICT manager argued:

The first thing and the foremost thing is skills, not money but skills. (ICT Manager, Interview 1)

However, it unfortunately appears that municipalities have a shortage of ICT skills when they are the level of government that needs these critically. As SALGA reports the skills shortage of the country has the most impact on local government and it was found that municipal staff members are under qualified and thus are not able to cope with ICT challenges (Smith \& Cohen, 2012). Respondents supported this as follows:

That is where the problem is, there is a lack of skills and a lack of understanding. (ICT Manager, Interview 5)

$70 \%$ of municipalities are running IT at a network operator level. Look at the adverts, they don't have IT managers. They have something called a network operator. Most local municipalities will have a network operator. Now that is a guy who is running around with a screwdriver and CD's in his pocket fixing emails. (ICT Manager, Workshop Transcripts) 
And they just don't have the skills sitting in government to be able to provide the infrastructure that we require and it's really slowed down a lot of the services. (Local Government Consultant, Interview 3)

The ICT sector is fast paced and ever growing and thus there is a challenge for municipalities to remain skilled in the different areas.

An issue in local government is the confusion over ICT 'buzzwords' e.g. e-government vs. e-governance, vs. digital divide, ICT governance, e-participation, m-participation, etc. There are various words being used, they are often not understood or have different meanings to different people in the municipalities. (Local Government Authority, Interview 2)

We are intimidated by a lot of these things captured in acronyms made up by various parties. (ICT Manager, Workshop Transcripts)

Governments are often cited as having insufficient ICT skills and this is coupled with a need to compete with the higher salaries often paid within the private sector (Schware, 2003). What concerned the respondents was that if the skills gap was not addressed it would continue to cost the municipalities. This was not only in reference to delays with the delivery of projects but also funds that were diverted to consultants as a means of temporarily buying the skills.

Managers don't understand the system they are very susceptible to the consultants... you think that is the best one and you implement it and it turns out to be a white elephant and they are gone by the time and it is half way through implementation (ICT Manager, Interview 5)

Some of the municipal ICT managers, however, were optimistic that skills and capacity could be improved in municipalities through internal initiatives. The lack of skills may be a current barrier however municipalities may consider strategies to build skills and capacity over time. One municipality for example initiated an internship program which provides students that are studying towards qualifications in ICT the opportunity to obtain work experience. This at the same time increases local skills and the capacity for the department since they have more resources for the internship period. They also have the option of employing the student in future where possible.

...that is why I have here for the information technology (IT) side work experience, any student within the municipality that is attending tertiary or secondary...doing information technology (IT) courses that requires work experience...I will consider taking them on for that period. In fact I have already had two through my hands and overall it has been very successful. He has got his diploma though the university and the other is a young student and she started just basic PC training. She finished her work experience. She has now gone back to college and is doing her course. So we are encouraging people and we are trying to keep them in the area so when a new company comes in we have an information technology (IT) skills base to draw from. And that is extremely important and it gives stability to the employer as well. (ICT Manager, Interview 1) 


\subsubsection{Funding}

Funding was raised at all the sessions as a significant barrier for the ICT departments in their effort to support the municipalities in delivering on their mandates. The lack of funding is echoed in the literature since various research studies highlight this as a concerning impediment (see, for example, Almarabeh and AbuAli (2010); Ebrahim and Irani (2005); Heeks (2002); Heeks et al. (2003); Tat-Kei Ho (2002); Janssen and Shu (2008); Wang (2009)). One of the respondents indicated that their ICT department was taken in-house after a long period of outsourcing parts of the IT function to different service providers. It was however difficult to convince the municipal manager on the issue of a budget:

After the municipal manager told me we had no budget, I questioned whether I should be here and eventually after about a month we managed to get some money from finance (ICT Manager, Interview 1)

My budget is... I call it a virtual budget. (ICT Manager, Interview 2)

If I had the budget this would be a first class department.(ICT Manager, Interview 1)

But we do struggle as far as finances are concerned. We are not bankrupt obviously. We manage our money; we manage our funding very strictly (ICT Manager, Interview 2)

Municipalities did however raise a means of coping with the limited funding. For example a culture of 'making do with what is in hand' (Baker \& Nelson, 2005; Ochara \& Mawela, 2015) appears to have assisted one smaller municipality. The notion that they did not feel overwhelmed but rather focused on what they did have rather than not, resonated.

I have trained my staff to think outside the box and to recycle and they are fantastic at it now. Slow to start, but as we have progressed they have got more and more into it and saying if we don't have it we will find a way. In ninety percent of the cases there is always an alternative. (ICT Manager, Interview 1)

Another option was to find additional ways of cutting costs. For example two municipalities indicated how they have switched to open source software:

Because of our situation we have taken big ideas and reduced them. (ICT Manager, Interview 1,pp 4)

Take note of this all our servers are now open source, they are no longer Microsoft. (ICT Manager, Interview 5)

The literature shows that for instance, some public organisations have moved to the open source software allowing them to experience some relief from funding pressures (Camara \& Fonseca, 2007; Sife, Lwoga, Sanga, et al., 2007). However, in the longer term, the ICT function may have to indicate to municipalities why allocating them supportive budgets is necessary in light of how they contribute to the community's development. 
Municipalities have so many competing priorities - it is critical to show how ICT can help e.g. with Local Economic Development or Service Delivery etc. (Local Government Authority, Interview 2)

One municipal ICT manager chose to look forward and maintain optimism despite the funding challenges:

The question of budget... Yes no municipality can say they have enough budget but you start somewhere. When I started we had one person now we are three, it simply means we are growing we are hoping that next time we will have 5. Let's not give up! (Municipal ICT Manager, Workshop Transcripts)

\subsection{Citizen factors}

\subsubsection{Trust}

Building citizen trust is important for enabling e-Government. (Bélanger \& Carter, 2008) indicate that trust in government is 'one's perceptions regarding the integrity and ability of the agency providing the service' (Bélanger \& Carter, 2008, p. 167). Some municipalities recognised the importance of building trust with citizens and highlighted their concerns.

There is a lot of mistrust between the community and the municipality and it has a very negative effect. (ICT Manager, Interview 1)

One municipality implemented an e-participation tool based on a short message service (SMS), and it took two years to convince community members to register their cell phone numbers on the system. However, through a strict policy of not abusing citizen information (e.g. not using data for campaigning for a particular political party), they showed their community that the municipality could be trusted. This supported the building of the Government to Citizen (G2C) relationship and increased the involvement of citizens in their e-participation system.

If there is a fault the people no longer phone technical they phone Information and communications technology (ICT) to find out why we didn't send out an SMS because they had no electricity for the last hour. We are getting noticed and we are getting interaction. It is not negative it is positive. (ICT Manager, Interview 1)

Thus once the relationship has been developed municipalities find a pull rather than a push scenario where citizens initiate the interactions. ICT has also manifested some problems:

ICT is the source of and solution to mistrust. When citizens have bad experiences e.g. they send a complaint and that leads to them not being given a tender or citizen's personal data is not handled responsibly that leads to issues with trust. Trust is broader not only focused on the e-participation mobile solution but also about how citizens' information is handled. (Local Government Authority Interview 2) 
Municipalities appear to believe that the results of building trust are positive and self-evident:

We gave a promise to the community that it will only be used for municipal purposes and not for third parties. Plus the fact that it would be non-political as well. And that is a thin line. A good example is the previous elections, a certain party wanted to send out an SMS and I blocked it. That was the turning point when people realized we had kept the promise we had given them. (ICT Manager, Interview 1)

Another factor which is very, very important to note, within the last two years the municipality has had not one service delivery protest. (ICT Manager, Interview 1)

It will be important to ensure that municipalities consistently include citizens in local government processes since trust is a foundational principle for e-Government (Bannister \& Connolly, 2011).

\subsubsection{Language implications}

South Africa recognizes 11 official languages and thus is faced with a challenge of ensuring that government caters appropriately to its citizens in their language of choice for service delivery. This is an area that municipalities need to be sensitive of. For example the local government authority assessed municipal websites and found that:

All municipal websites are in English! (Local Government Authority Manager, Interview 2)

One municipality was taking small steps towards acknowledging the language dynamics of their communities:

Even down to our SMS's we are now finding we are sending out SMS's in Zulu and the odd one out in Afrikaans ${ }^{3}$. If it is only being targeted to an area that speaks that then we translate it, but ninety eight percent are English. (ICT Manager, Interview 1)

Research indicates that there are benefits for ensuring that e-Government services are available in the language of choice for citizens. One study found that the consideration of language in a bi-lingual or multi-lingual society in e-Government improved citizens' trust (Segovia, Jennex, \& Beatty, 2009). Another study hypothesised that for certain citizens reduced language options such as the lack of their mother tongue for interacting with e-Government may be a potential barrier for adoption (Shareef, Kumar, Kumar, \& Dwivedi, 2011).

\footnotetext{
${ }^{3}$ Zulu and Afrikaans are two of the 11 official languages of South Africa.
} 


\subsubsection{E-Participation in municipalities}

A World Bank report found that the voice of the citizens appears to have been lost due to government's focus on centralised planning and meeting targets without considering how citizens would prefer the services to be delivered. Yet, the area of citizen participation is important for the improvement and institutionalisation of political accountability of the public sector towards its citizens (The World Bank, 2011). Participation of citizens is evident in the legal frameworks of South Africa yet it is failing to come through in delivery. Accordingly, the use of technology to support participatory governance and service delivery requires attention in the municipalities. However, municipalities were still relying on traditional mediums for citizen participation. For example some municipalities outlined in their stakeholder engagement plan that the participation of stakeholders would be encouraged through meetings, letters, email, special events, mass media and other programmes. As one respondent explained citizens were expected to be involved in the Integrated Development Planning Processes (IDP) which runs every five years.

How do you involve citizens in ICT in the province? Usually it is through the IDP. They don't directly interface with ICT as such; it is mainly through the IDP. The translation of the IDP is the ICT programs. When the projects become operational then we see the effectiveness of the ICT projects... (ICT Manager, Interview 5)

Feedback on the services is usually through the call centre, through the IDP session meetings or ward committee meetings and the tools are the customer care relations management system. E-participation is very critical because e-participation if done correctly can avoid or mitigate protests, it really can. (ICT Manager, Interview 5)

It was encouraging to note that municipalities do recognise that participation requires feedback to and from citizens and their local government.

The participation of course is a two way street... One of the things on the e-participation is we want to do that kind of thing where people can inform us of their views on certain things. (ICT Manager, interview 5)

Yet, from the discussion with and analysis of the municipalities they had not effectively considered how ICTs may support this two-way dialogue and decision making for service delivery. This assertion was supported by the Public Service Commission's ${ }^{4}$ findings that in municipalities "part of the implementation weaknesses are the non-involvement of beneficiary communities in the planning and implementation of programs" (Public Service Commission, 2008, p. 40). The frustration of the ICT managers was palpable in the workshop and interviews further pointing to a gap between the rhetoric of policy designers (national government) and the practical experiences of the implementers (local government municipalities).

\footnotetext{
${ }^{4}$ The Public Service Commission is an independent and impartial body mandated by the South African Constitution to investigate and evaluate the performance of the public administration.
} 


\section{CONCLUSION AND RESEARCH CONTRIBUTION}

E-Government has historically been associated with disappointing outcomes. The paper contributes to the ongoing discussion regarding the challenges facing e-government implementations in developing nations. This paper reflected on several themes that arose from discussions with municipal ICT representatives. The paper presented the outcomes of interviews and a workshop on the role of ICTs towards the development of communities. The qualitative primary data was analysed thematically to tease out the barriers for e-Government. The respondents indicated that their most pertinent issues were around areas such as lack of funding, shortage of skills, poor leadership and the profile of ICTs in municipalities. The data mirrored what was found in the existing literature indicating that South Africa's experiences are similar to its counterparts in the developing world. The findings show that for ICTs to be transformational there needs to be a consideration of the political context, culture and business processes bearing in mind the multi-actor environment and organisational setting (Weerakkody, 2009). Ultimately, the respondents believed that ICTs have a role in supporting and enabling development goals.

Lessons and practical recommendations offered by respondents include:

- Raising the profile of the ICT department within the municipal organisational structure so that it is viewed as a strategic function that supports the municipal objectives.

- Addressing the culture of working in silos across the tiers of government for integrated and citizen focused service delivery.

- The ICT department to find a champion who will support their projects. The person is ideally in a senior position and holds strong relationships with peers, junior staff and political leadership.

- Initiating cost effective means to increase capacity and ICT skills such as internship programmes.

- Due to limited funding and resources municipalities should consider alternatives available such as open source solutions.

- Consider additional mechanisms to encourage the participation of citizens and foster dialogue. Citizens should be consulted when ICT enabled programmes are implemented in their communities.

The above offer options to be considered by municipalities taking into account their respective contexts.

The study may be extended to incorporate further interviews with local government since it was limited to a workshop of 40 representatives and five one-on-one interviews. A future extension of the study can also include the investigation of how current organisational values of public sector institutions should be changed and the adoption of new values supporting the implementation of e-Government. This proposed study may include an exploration of how to align individual values to the requirements of e-Governments from a IS change management perspective or other organisational change research domains. Additionally, this study focused on the government perspective whereas 
future studies may collect data from a citizen perspective since they are ultimately expected to use and benefit from e-Government systems.

\section{References}

Abrahams, L. \& Newton-Reid, L. (2007). eGovernance for social and local economic development. LOG-IN Africa Third Technical Progress Report.

Alexander, P. (2010). Rebellion of the poor: South Africa's service delivery protests-A preliminary analysis. Review of African Political Economy, 37(123), 25-40. https://doi.org/10.1080/ 03056241003637870

Ali, M. \& Bailur, S. (2007). The challenge of 'sustainability' in ICT4D-Is bricolage the answer? In Proceedings of the 9th International Conference on Social Implications of Computers in Developing Countries, São Paulo, Brazil.

Almarabeh, T. \& AbuAli, A. (2010). A general framework for e-government: Definition maturity challenges, opportunities, and success. European Journal of Scientific Research, 39(1), 29-42.

Alsaghier, H., Ford, M., Nguyen, A., \& Hexel, R. (2011). Conceptualising citizens' trust in e-government: Application of Q methodology. Leading Issues in E-Government, 1, 204.

Andrade, A. \& Joia, L. A. (2012). Organizational structure and ICT strategies in the Brazilian judiciary system. Government Information Quarterly, 29, S32-S42.

Anthopoulos, L., Reddick, C. G., Giannakidou, I., \& Mavridis, N. (2016). Why e-government projects fail? An analysis of the Healthcare.gov website. Government Information Quarterly, 33(1), 161-173.

Baker, T. \& Nelson, R. E. (2005). Creating something from nothing: Resource construction through entrepreneurial bricolage. Administrative Science Quarterly, 50(3), 329-366. https://doi.org/ 10.2189/asqu.2005.50.3.329

Bannister, F. \& Connolly, R. (2011). Trust and transformational government: A proposed framework for research. Government Information Quarterly, 28(2), 137-147. https://doi.org/10.1016/j. giq.2010.06.010

Bélanger, F. \& Carter, L. (2008). Trust and risk in e-government adoption. The Journal of Strategic Information Systems, 17(2), 165-176. https://doi.org/10.1016/j.jsis.2007.12.002

Braun, V. \& Clarke, V. (2006). Using thematic analysis in psychology. Qualitative Research in Psychology, $3(2), 77-101$.

Brown, D. (2005). Electronic government and public administration. International Review of Administrative Sciences, 71(2), 241-254. https://doi.org/10.1177/0020852305053883

Bwalya, K. J. (2009). Factors affecting adoption of e-government in Zambia. The Electronic Journal of Information Systems in Developing Countries, 38.

Camara, G. \& Fonseca, F. (2007). Information policies and open source software in developing countries. Journal of the Association for Information Science and Technology, 58(1), 121-132. https://doi.org/10.1002/asi.20444 
Chen, A. J., Pan, S. L., Zhang, J., Huang, W. W., \& Zhu, S. (2009). Managing e-government implementation in China: A process perspective. Information \& Management, 46(4), 203-212. https://doi.org/10.1016/j.im.2009.02.002

Chen, Y.-C. \& Gant, J. (2002). Transforming local e-government services: The use of application service providers. Government Information Quarterly, 18(4), 343-355. https://doi.org/10. 1016/S0740-624X(01)00090-9

Chou, T.-C., Chen, J.-R., \& Pu, C.-K. (2008). Exploring the collective actions of public servants in e-government development. Decision Support Systems, 45(2), 251-265. https://doi.org/10. 1016/j.dss.2007.02.005

City of Tshwane Mayoral Committee. (2008, June). City of Tshwane stakeholder management framework. Retrieved from http://www.tshwane.gov.za/sites/Council/Ofiice-Of-TheExecutive-Mayor/Communication/3.\%20Approved\%20Stakeholder\%20Liaison.pdf\# search=stakeholder

Cloete, F. (2012). E-government lessons from South Africa 2001-2011: Institutions, state of progress and measurement: Section II: Country perspectives on e-government emergence. The African Journal of information and communication, 2012(12), 128-142.

Dada, D. (2006). The failure of e-government in developing countries: A literature review. The Electronic Journal of Information Systems in Developing Countries, 26.

Damianides, M. (2005). Sarbanes-Oxley and IT governance: New guidance on IT control and compliance. Information Systems Management, 22(1), 77-85. https://doi.org/10.1201/ 1078/44912.22.1.20051201/85741.9

Davison, R. M., Wagner, C., \& Ma, L. C. (2005). From government to e-government: A transition model. Information Technology \& People, 18(3), 280-299. https:// doi.org/10.1108/ 09593840510615888

De Haes, S. \& Van Grembergen, W. (2009). An exploratory study into IT governance implementations and its impact on business/IT alignment. Information Systems Management, 26(2), 123-137. https://doi.org/10.1080/10580530902794786

Devadoss, P. R., Pan, S. L., \& Huang, J. C. (2003). Structurational analysis of e-government initiatives: A case study of SCO. Decision Support Systems, 34(3), 253-269. https://doi.org/10.1016/ S0167-9236(02)00120-3

Dwivedi, Y. K., Williams, M. D., Rana, N. P., \& Williams, J. (2011). Reflecting on e-government research: Toward a taxonomy of theories and theoretical constructs. International Journal of Electronic Government Research, 7(4), 64-88. https://doi.org/10.4018/jegr.2011100105

Ebbers, W. E. \& Van Dijk, J. A. (2007). Resistance and support to electronic government, building a model of innovation. Government Information Quarterly, 24(3), 554-575. https://doi.org/10. 1016/j.giq.2006.09.008

Ebrahim, Z. \& Irani, Z. (2005). E-government adoption: Architecture and barriers. Business Process Management Journal, 11(5), 589-611. https://doi.org/10.1108/14637150510619902

Economist Intelligence Unit. (2010). Digital economy rankings 2010: Beyond e-readiness. A report from the Economist Intelligence Unit, written in co-operation with the IBM Institute for Business Value. 
Edmiston, K. D. (2003). State and local e-government: Prospects and challenges. The American Review of Public Administration, 33(1), 20-45. https://doi.org/10.1177/0275074002250255

Evans, D. \& Yen, D. C. (2006). E-Government: Evolving relationship of citizens and government, domestic, and international development. Government Information Quarterly, 23(2), 207-235. https://doi.org/10.1016/j.giq.2005.11.004

Furuholt, B. \& Wahid, F. (2008). E-government challenges and the role of political leadership in Indonesia: The case of Sragen. In Hawaii International Conference on System Sciences, Proceedings of the 41st Annual (pp. 411-411). IEEE. https://doi.org/10.1109/hicss.2008.134

Gauld, R. (2007). Public sector information system project failures: Lessons from a New Zealand hospital organization. Government Information Quarterly, 24(1), 102-114. https://doi.org/ 10.1016/j.giq.2006.02.010

Guha, J. \& Chakrabarti, B. (2014). Making e-government work: Adopting the network approach. Government Information Quarterly, 31(2), 327-336. https://doi.org/10.1016/j.giq.2013. 11.008

Harindranath, G. \& Sein, M. K. (2007). Revisiting the role of ICT in development. In Proceedings of the 9th International Conference on Social Implications of Computers in Developing Countries, São Paulo, Brazil.

Heeks, R. (2002). e-Government in Africa: Promise and practice. Information Polity, 7(2, 3), 97-114.

Heeks, R. et al. (2003). Most eGovernment-for-development projects fail: How can risks be reduced? University of Manchester: Institute for Development Policy and Management.

Heeks, R. (2005). e-Government as a carrier of context. Journal of Public Policy, 25(1), 51-74. https://doi.org/10.1017/S0143814X05000206

Heeks, R. (2010). Do information and communication technologies (icts) contribute to development? Journal of International Development, 22(5), 625-640.

Heeks, R. \& Molla, A. (2009). Compendium on impact assessment of ICT-for-development projects. Manchester, UK: University of Manchester Centre for Development Informatics. Technology and Social Change Group (TASCHA), University of Washington, Seattle, WA, US. Retrieved from http://tascha.uw.edu/publications/global-impact-study-compendium-on-impactassessment-of-ict-for-development-projects/

Independent Evaluation Group, The World Bank. (2011). An evaluation of World Bank activities in Information and Communication Technologies: Capturing technology for development. Retrieved from http://ieg.worldbankgroup.org/Data/reports/ict_evaluation.pdf

Irani, Z., Elliman, T., \& Jackson, P. (2007). Electronic transformation of government in the UK: A research agenda. European Journal of Information Systems, 16(4), 327-335. https://doi.org/ 10.1057/palgrave.ejis. 3000698

Irani, Z., Love, P. E., \& Jones, S. (2008). Learning lessons from evaluating eGovernment: Reflective case experiences that support transformational government. The Journal of Strategic Information Systems, 17(2), 155-164. https://doi.org/10.1016/j.jsis.2007.12.005

Irani, Z., Sahraoui, S., Ozkan, S., Ghoneim, A., \& Elliman, T. (2007). T-government for benefit realisation. In Proceedings of European and Mediterranean Conference on Information Systems (pp. 1-11). 
Janssen, M. \& Shu, W. S. (2008). Transformational government: Basics and key issues. In Proceedings of the 2nd International Conference on Theory and Practice of Electronic Governance (pp. 117122). ACM. https://doi.org/10.1145/1509096.1509120

Karunasena, K., Deng, H., \& Singh, M. (2011). Measuring the public value of e-government: A case study from Sri Lanka. Transforming Government: People, Process and Policy, 5(1), 81-99.

Krishnaswamy, G. (2006). E-services in government: Why do we need strategies for capacity building and capacity utilization? Delivering E-government, 15.

Mawela, T., Ochara, N. M., \& Twinomurinzi, H. (2016). e-Government implementation: Lessons from South African municipalities. In Proceedings of the Annual Conference of the South African Institute of Computer Scientists and Information Technologists (SAICSIT '16), Johannesburg, South Africa. ACM.

Moon, M. J. (2002). The evolution of e-government among municipalities: Rhetoric or reality? Public Administration Review, 62(4), 424-433.

Müller, S. D. \& Skau, S. A. (2015). Success factors influencing implementation of e-government at different stages of maturity: A literature review. International Journal of Electronic Governance, $7(2), 136-170$.

Mutula, S. M. (2005). Peculiarities of the digital divide in sub-Saharan Africa. Program, 39(2), 122-138. https://doi.org/10.1108/00330330510595706

Mutula, S. M. \& Mostert, J. (2010). Challenges and opportunities of e-government in South Africa. The Electronic Library, 28(1), 38-53. https://doi.org/10.1108/02640471011023360

Ndou, V. (2004). E-government for developing countries: opportunities and challenges. The Electronic Journal of Information Systems in Developing Countries, 18.

Nkosi, M. \& Mekuria, F. (2010). Mobile government for improved public service provision in South Africa. In IST-Africa, 2010 (pp. 1-8). IEEE.

Nurdin, N., Stockdale, R., \& Scheepers, H. (2012). Organizational adaptation to sustain information technology: The case of e-government in developing countries. Electronic Journal of e-Government, 10(1), 70-83.

Ochara, N. M. \& Mawela, T. (2015). Enabling social sustainability of e-participation through mobile technology. Information Technology for Development, 21(2), 205-228. https://doi.org/10. $1080 / 02681102.2013 .833888$

Oghogho, I. (2013). ICT for national development in Nigeria: Creating an enabling environment. International Journal of Engineering and Applied Sciences, 3(2), 59-66.

Public Service Commission. (2008, March). State of the Public Service report 2008. Retrieved from http://www.psc.gov.za/documents/2008/SOPS\%20Report.pdf

Reffat, R. (2003). Developing a successful e-government. Proc. Sympos. e-Government: Opportunities and Challenge, Muscat Municipality, Oman, IV1-IV13.

Rowley, J. (2011). e-Government stakeholders-Who are they and what do they want? International Journal of Information Management, 31(1), 53-62.

Scholl, H. J. (2005). E-government-induced business process change (BPC): An empirical study of current practices. International Journal of Electronic Government Research (IJEGR), 1(2), 27-49. 
Schuppan, T. (2009). E-Government in developing countries: Experiences from sub-Saharan Africa. Government Information Quarterly, 26(1), 118-127.

Schware, R. (2003). Information and communications technology (ICT) agencies: Functions, structures, and best operational practices. info, 5(3), 3-7.

Segovia, R. H., Jennex, M. E., \& Beatty, J. (2009). Paralingual web design and trust in e-government. Web Technologies: Concepts, Methodologies, Tools, and Applications: Concepts, Methodologies, Tools, and Applications, 277.

Sein, M. K. \& Harindranath, G. (2004). Conceptualizing the ICT artifact: Toward understanding the role of ICT in national development. The Information Society, 20(1), 15-24.

Shareef, M. A., Kumar, V., Kumar, U., \& Dwivedi, Y. K. (2011). e-Government Adoption Model (GAM): Differing service maturity levels. Government Information Quarterly, 28(1), 17-35.

Sife, A., Lwoga, E., Sanga, C., et al. (2007). New technologies for teaching and learning: Challenges for higher learning institutions in developing countries. International Journal of Education and Development Using ICT, 3(2).

Smith, P. \& Cohen, D. (2012, June). A municipal guide/roadmap to successful ICT governance. South African Local Government Association. Retrieved from http://Igict.org.za/document/ municipal-guide-roadmap-successful-ict-governance

South African Local Government Association. (2014). About municipalities. Retrieved from http: //www.salga.org.za/Municipalities\%20AM.html

Statistics South Africa. (2011). Census 2011: Key results. Retrieved from http://www.statssa.gov. za/census/census_2011/census_products/Census_2011_Key_results.pdf

Tat-Kei Ho, A. (2002). Reinventing local governments and the e-government initiative. Public Administration Review, 62(4), 434-444. https://doi.org/10.1111/0033-3352.00197

The World Bank. (2011, March). Accountability in public services in South Africa: Selected issues.

Thomas, P. (2009). Bhoomi, Gyan Ganga, e-governance and the right to information: ICTs and development in India. Telematics and Informatics, 26(1), 20-31.

United Nations Secretariat Department of Economic and Social Affairs. (2008a). United Nations E-Government Survey 2008: From E-Government to Connected Governance. UNPAN. Retrieved from http://unpan1.un.org/intradoc/groups/public/documents/UN/UNPAN028607.pdf

United Nations Secretariat Department of Economic and Social Affairs. (2008b). United Nations E-Government Survey 2012: E-Government for the People. UNPAN. Retrieved from http: //unpan1.un.org/intradoc/groups/public/documents/un/unpan048065.pdf

United Nations Secretariat Department of Economic and Social Affairs. (2014). United Nations E-Government Survey 2014: E-Government for the Future We Want. Retrieved from https:// publicadministration.un.org/egovkb/Portals/egovkb/Documents/un/2014-Survey/EGov_Complete_Survey-2014.pdf

Van Veenstra, A. F., Klievink, B., \& Janssen, M. (2011). Barriers and impediments to transformational government: Insights from literature and practice. Electronic Government, An International Journal, 8(2-3), 226-241. https://doi.org/10.1504/EG.2011.039838 
Wang, Y.-J. (2009). Rethinking E-Government Services Session 3: Serving Citizens-Becoming Userfocused in the Provision of E-Government Services. Retrieved from https://www.oecd.org/ gov/digital-government/44590340.pdf

Warkentin, M., Gefen, D., Pavlou, P. A., \& Rose, G. M. (2002). Encouraging citizen adoption of e-government by building trust. Electronic Markets, 12(3), 157-162. https://doi.org/10. 1080/101967802320245929

Weerakkody, V. (2009). Handbook of research on ICT-enabled transformational government: A global perspective. IGI Global. https://doi.org/10.4018/978-1-60566-390-6

Weerakkody, V., Irani, Z., Lee, H., Osman, I., \& Hindi, N. (2015). E-government implementation: A bird's eye view of issues relating to costs, opportunities, benefits and risks. Information Systems Frontiers, 17(4), 889. https://doi.org/10.1007/s10796-013-9472-3 